\title{
EFFECT OF SUBSTITUTION OF WHEAT FLOUR WITH QUINOA FLOUR ON QUALITY OF PAN BREAD AND BISCUIT
}

\author{
Moawad', E.M.M., Rizk², I.R.S., Kishk ${ }^{2}$, Y.F.M. and Youssif ${ }^{3}$, M.R.G.
}

1- General Authority for Supply Commodities, Ministry of Supply and Internal Trade, 99 St. Al- Kasr El-Ainy, Cairo, Egypt

2- Food Sci. Dept., Fac. of Agric., Ain Shams Univ., 68 Hadayek Shoubra 11241, Cairo, Egypt

3- Bread and Pasta Research Dept., Food Technology Research Institute, Agric. Research Centre, Giza, Egypt

*Corresponding author: emad.coach@yahoo.com

\section{ABSTRACT}

This study was carried out to investigate the effect of partial substitution (5, 10 and15\%) of wheat flour (72\% ext.) by whole meal quinoa flour (QF) on quality parameter of pan bread. QF contained the highest percentage of protein, Lipids, ash and crude fiber. Also, QF contained the highest amount of essential amino acids such as (threonine, methionine, lysine and histidine). From the results, it could be seen that, water absorption and degree of softening increased by increasing the substitution levels, but stability, resistance to extensions and energy of dough decreased. The addition of QF adversely affected on the specific volume of pan bread. The lightness $\left(L^{*}\right)$ and yellowness $\left(b^{*}\right)$ of pan bread decreased, but redness $\left(a^{*}\right)$ increased gradually by increasing QF. Evaluation of the organoleptic properties of pan bread revealed that no significant differences $(P \geq 0.05)$ between control sample and bread samples contained QF for taste and summitry form. The bread contained QF had higher score for crust color, pore size and overall acceptability than control sample. Hardness (g) of pan bread increased and springiness decreased gradually during storage of bread at $\left(25^{\circ} \mathrm{C} \pm 2\right)$. The rate of staling of bread contained QF lower than control sample. Gluten - free biscuit made from 100\%QF contained the highest percentage of protein, lipids, ash and crude fiber compared to that of corn and rice - quinoa composite flour. The addition of corn and rice flour adversely affected on the thickness, diameter and spread ratio. The highest spread ratio was noticed in the biscuit made from $100 \%$ QF. It is worth mentioning that the biscuit made from $100 \%$ QF or that of corn and rice - quinoa composite flour gave the biscuit with sensory acceptable. On the other hand, it could be noticed to that the biscuit contained high level of quinoa flour was darker in compared to another samples.

Keywords: Wheat flour, Quinoa flour, Corn flour, Rice flour, Rheological properties, Pan Bread, Gluten free biscuit

\section{INTRODUCTION}

Bread is an important staple food in both developed and developing countries. Wheat (Triticum aestivum) flour of both hard and soft wheat classes has been the major ingredients of leavened bread for many years because of its functional proteins. Many efforts have been carried out to promote the use of composite flour, in which a portion of wheat flour is replaced by locally grown crops, to be used in bread, thereby decreasing the cost associated with important wheat (Olaoya et al 2006).

Cookies-type biscuits have long shelf life and wide acceptance by consumers of all ages (Mareti et al 2010), making these items attractive in the development of alternative products, such as gluten-free foods. In the design of new products, parameters such as volume, color and texture which directly influence consumer acceptance, should be considered (Bassinello et al 2011). Within this 
context, the experimental design of mixtures is a toll that always modeling by simulating and optimizing certain properties of the ingredients in a formulation.

Quinoa is a gluten-free pseudo-cereal that contains a high amount of fiber, high biological-value proteins, essential fatty acids ( $\omega-3$ and $\omega-6)$, vitamins, and minerals (Stikic et al 2012).Quinoa can also be used in the bakery industry because the starch present in the seeds has properties similar to those found in wheat (Gómez-Caravaca et al 2011). On the other hand, the addition of quinoa flour has shown positive effects on the sensory characteristics of bakery products such as bread and cookies (Stikic et al 2012). Nutritionally, quinoa is a super grain and the World Health Organization has rated quinoa as equivalent to milk as it contains high levels of potassium, riboflavin, B6, niacin and thiamin along with magnesium, zinc, copper and manganese. Therefore, quinoa flour alone or fortified with other gluten free flour can represent a healthy alternative for people with celiac disease (CD), Gluten-free breads and cookies are principally based on flour from rice or maize with low content and poor-quality proteins (Bhaduri, 2013).

Therefore, the objective of this study has been performed to evaluate the effect of substitution of wheat flour with different levels of whole quinoa meal on the quality properties of the flour blends, as well as to study the effect on physical and quality criteria of produced pan bread. As well as, the influence of quinoa flour on gluten - free biscuit.

\section{MATERIALS AND METHODS}

\section{Materials}

Wheat flour (Triticum aestivum) (72\% extraction) was obtained from five stars milling Co., Suisse, Egypt. Corn flour (Zea mays) was obtained from Union for food industries Co., Egypt. Rice flour (Oryza sativa) was obtained from King " M" for food industries Co., Egypt.

Quinoa seed (Chenopodium quinoa Willd.) was obtained from Egyptian Natural Oil Co., Cairo, Egypt, during 2016 season.

All Other ingredients, Instant active dry yeast (IADY) (Saccharomyces cerevisiae), sucrose, salt, vegetable corn oil, baking powder, butter, vanillin and lecithin were obtained from the local market, Cairo, Egypt.

All chemicals used in the estimation and analysis in this study were analytical grade.

\section{Methods}

\section{Preparation of quinoa flour}

The quinoa seeds were cleaned to drown of dust and other foreign materials. The seeds were washed many times with cold water until there was no more foam in the washing water to remove saponins, and then they were dried at $50^{\circ} \mathrm{C}$ for 12 $\mathrm{h}$ in electric oven. The quinoa seeds were milled to fine powder using a Commercial electric mill stainless steel (More Blender mill, Model Type No: MB355 , China) and sifted through a 60 mesh to obtain whole meal quinoa flour Rosell et al (2009).

\section{Preparation of composite flour}

Strong wheat flour (SWF) was partially substituted by 5,10 and $15 \%$ of quinoa flour (QF) for used to prepared pan bread. QF was partially substituted by corn and rice flour for used prepared gluten- free biscuit. The flour mixtures were individually, blended homogenized then packed in polyethylene bags which tightly closed and stored at $-18^{\circ} \mathrm{C}$ until used.

\section{Pan bread processing}

Pan bread was prepared according to straightdough procedure for Cauvain and Linda (2007) with the following recipe: wheat flour (72\% ext.) $(1000 \mathrm{~g})$, IADY $(20 \mathrm{~g})$, salt $(10 \mathrm{~g})$, sucrose $(10 \mathrm{~g})$ and vegetable corn oil $(9 \mathrm{~g})$ and water according to Farinograph water absorption.

\section{Gluten - free biscuit processing}

Biscuit was prepared according to the method described by (Wade, 1988)with the following recipe: composite flour (quinoa, corn and rice flour) $(500 \mathrm{~g})$, butter $(80 \mathrm{~g})$, sucrose $(150 \mathrm{~g})$, salt $(2.5 \mathrm{~g})$, baking powder $(18 \mathrm{~g})$, lecithin $(3 \mathrm{~g})$, vanillin $(1.25 \mathrm{~g})$ and water $(75 \mathrm{~g})$.

\section{Analytical methods}

\section{Chemical analysis}

Moisture content, crude protein, lipids, ash and crude fiber contents were determined according to A.A.C.C. (2012). Nitrogen free extract (NFE) was calculated by differences. 
of pan bread and biscuit

\section{Determination of Amino Acids}

Amino acids profile of strong wheat, quinoa, corn and rice flours were determined according the method described in A.O.A.C. (2000) using Biochrom 20 automatic high performance amino acid analyzer.

\section{Rheological properties}

Rheological properties of the various blends were determined by Brabender Farinograph and Extensograph instruments according to A.A.C.C. (2012).

\section{Physical characteristics}

\section{Pan bread}

The weight $(\mathrm{g})$ of pan bread was determined after cooling for $1 \mathrm{~h}$., volume $\left(\mathrm{cm}^{3}\right)$ was measured by Volume Measurement BVM - L 370 apparatus by automated laser topography (A.A.C.C., 2012). Specific volume $\left(\mathrm{cm}^{3} / \mathrm{g}\right)$ was calculated by dividing the volume $\left(\mathrm{cm}^{3}\right)$ by their weight $(\mathrm{g})$.

\section{Gluten - free biscuit}

According to Sai-Manohar and Harids-Rao (1997), the diameter (D) and thickness ( $T$ ) of six biscuits were measured in millimeter by placing them edge to edge and by stacking one above the other, respectively. To obtain the average, measurements were made by rearranging and restacking. Spread ratio was calculated by dividing diameter of biscuit $(\mathrm{mm})$ by their thickness $(\mathrm{mm})$.

The weight and volume of six biscuits was determined after cooling for $1 \mathrm{~h}$. The volume $\left(\mathrm{cm}^{3}\right)$ was measured by rape seed displaced by six biscuits. Specific volume was calculated by dividing volume $\left(\mathrm{cm}^{3}\right)$ by biscuit weigh $(\mathrm{g})$.

\section{Organoleptic evaluation}

\section{Pan bread}

Pan bread was evaluated for crust color, crumb color, symmetry form, pore size, uniformity of pore size, taste and overall acceptability according to the method of Larmond (1970) using a 9 points scale (1- extremely inferior, 2- Much inferior, 3Moderate inferior, 4- Slight inferior, 5- Equal to $\mathrm{R}$ (control), 6- Slight better, 7- Moderate better, 8Much better, 9- Extreme better).

\section{Gluten - free biscuit}

Biscuit was evaluated for crust color, surface characteristics, crumb color, texture, mouth feel and taste. The characteristics were scored from 10 points for each according to Nandeesh et al (2011).

Texture properties of pan bread and gluten free biscuit

Texture properties of pan bread and gluten free biscuit were determined by using penetrometer instrument, Texture properties of bread and biscuit samples were measured by using a Texture analyzer TVT-300XP (Tex Vol Instruments AB, Viken, Sweden), according to A.A.C.C. (2012).

Color properties of pan bread and gluten - free biscuit

The crust and crumb color of pan bread and crust color of gluten - free biscuit were determined depending on the method substantive by Tong et al (2010). The colors $L^{*}$, $a^{*}$ and $b^{*}$ values were evaluated using a Konica Minolta CR-410 Chroma meter (Konica Minolta, Sensing, INC., Japan).

\section{Statistical analysis}

The obtained results were statistically analyzed by using SPSS computer software (SPSS, 2000). The statistical was performed by analysis of variance (ANOVA) and significant differences among Duncan's multiple test at $(P \leq 0.05)$ according to Waller and Duncan (1969).

\section{RESULTES AND DISCUSSION}

\section{Chemical composition of samples under re- search}

The proximate composition of wheat, whole meal quinoa, corn and rice flour which commercially used for production of white pan bread and biscuit are presented in Table (1). The results showed that, there were noticed significant difference $(p \leq 0.05)$ between quinoa flour and strong wheat, corn and rice flour in crude protein, lipids, crude fiber, ash and nitrogen free extract (NFE). Quinoa flour had highest amount of crude protein, lipids, crude fiber and ash compared to another raw material under investigation. Quinoa flour had 23,804, 494 and $490 \%$ of crude protein, lipids, crude fiber 
and ash more than wheat flour, but wheat flour had $17 \%$ in NFE more than quinoa flour. The results are agreement to result by Enriquez et al (2003) and Atef et al (2014). Milovanovie et al (2014) reported that, quinoa flour contained $12.6 \%$ protein, $6.02 \%$ oil and $3.03 \%$ crude fiber.

Table 1. Proximate composition of wheat, quinoa, corn and rice flour (\% on dry weight basis)

\begin{tabular}{|c|c|c|c|c|c|c|}
\hline Flour samples & Moisture & $\begin{array}{c}\text { Crude } \\
\text { protein }\end{array}$ & Lipids & $\begin{array}{c}\text { Crude } \\
\text { Fiber }\end{array}$ & Ash & NFE * $^{*}$ \\
\hline Strong wheat flour (72\% ext.) (SWF) & $12.60^{\mathrm{a}}$ & $12.25^{\mathrm{b}}$ & $0.70^{\mathrm{d}}$ & $0.64^{\mathrm{c}}$ & $0.63^{\mathrm{c}}$ & $85.78^{\mathrm{d}}$ \\
Whole meal quinoa flour (QF) & $11.36^{\mathrm{d}}$ & $15.10^{\mathrm{a}}$ & $6.33^{\mathrm{a}}$ & $3.80^{\mathrm{a}}$ & $3.72^{\mathrm{a}}$ & $71.05^{\mathrm{e}}$ \\
Corn flour (CF) & $12.12^{\mathrm{b}}$ & $5.45^{\mathrm{d}}$ & $1.52^{\mathrm{b}}$ & $1.76^{\mathrm{b}}$ & $1.14^{\mathrm{b}}$ & $90.13^{\mathrm{b}}$ \\
Rice flour (RF) & $10.40^{\mathrm{e}}$ & $6.20^{\mathrm{c}}$ & $0.93^{\mathrm{c}}$ & $0.62^{\mathrm{c}}$ & $0.60^{\mathrm{cd}}$ & $91.65^{\mathrm{a}}$ \\
\hline
\end{tabular}

${ }^{*}$ Means in the same column followed by different letters are significantly different $(p \leq 0.05)$

${ }^{*} \mathrm{NFE}=$ Nitrogen free extract, was calculated by difference.

On the other hand, generally from the results in Table (1), it is clear to notice that (protein, lipids, crude fiber and ash) of quinoa flour were higher than those of corn and rice flour, while NFE in corn and rice flour higher than that in quinoa flour. These results are agreement with Tharise et al (2014) and Adeyeye et al (2017).

\section{Amino acids contents in raw materials}

Data given in Table (2) showed that the amino acid composition ( $\mathrm{g}$ amino acid / $100 \mathrm{~g}$ protein) of wheat, quinoa, corn and rice flour. The obtained results indicated that, the amount of total essential amino acids content of quinoa, corn and rice flour were relatively high total essential amino acids compared to wheat flour ( $72 \%$ ext.). It was 38.48 , 43.85 and $43.39 \mathrm{~g} / 100 \mathrm{~g}$ protein for quinoa, corn and rice flour, respectively compared to wheat flour (34.29 g / $100 \mathrm{~g}$ protein). On the other hand, threonine, methionine and lysine in quinoa flour were higher than those in wheat flour. Also, those essential amino acids in corn and rice flour were higher than those in wheat flour.

Results in agreement with Gesinski and Nowak (2011). Also, Atef et al (2014) reported that total essential amino acid contents of quinoa were higher than in wheat flour. Also, they showed that, the contents of threonine, methionine, valine, histidine and lysine in quinoa were higher than those in wheat flour protein.

Also, from the data in Table (2) the contents of amino acids (cysteine, leucine and histidine) in corn flour were higher than those in wheat and quinoa flour. Rice flour contained the higher amounts of valine, isoleucine, tyrosine and phenylalanine compared to another raw material under investigation. Wheat flour contained the higher amounts of non - essential amino acids compared to quinoa, corn and rice flour.

Parameters protein quality of wheat, quinoa, corn and rice flour presented in Table (2) showed that, the quality of protein parameters (calculated protein efficiency ratio (C- PER), chemical score (CS), essential amino acid index (EAAl), biological value (BV) and first limiting amino acid (First$L A A)$ ), were higher in $Q F, C F$ and $R F$ than WF. Generally, these parameters increase about (25 $100 \%)$ compared to wheat flour. results indicated that QF, CF and, RF can be utilized as a good protein sources were compared with reference to the FAO / WHO (1990).

\section{Rheological properties of wheat flour and its blends with quinoa flour}

The results in Table (3) showed that the effect of substituted strong wheat flour (72\% ext. ) with 5 , 10 and 15\%whole meal quinoa flour (QF) on Farinograph and Extensograph parameters. From the results, it could be observed that by increasing the substitution levels at the blends from to 5 to $25 \%$ of (QF), the water absorption was found to be gradually increased in all blends as compared were control samples. The increase in water absorption may be due to the increase in protein and crude fiber contents in QF (Enriquez et al 2003). The arrival time and dough development time showed slightly increased by increasing the substitution level of QF. Similar effects were observed by Atef et al (2014). As shown in the obtained data (Table 3), with the increasing proportion of the QF in SWF blends led to a progressive decrease in the dough stability (min). Also, degree of softening of the dough was increased by increasing levels of substitution by QF. These results are in agreement with those obtained by Enriquez et al (2003). 

of pan bread and biscuit

Table 2. Amino acids profile of wheat, quinoa, corn and rice flour (g AA/ $100 \mathrm{~g}$ of protein)

\begin{tabular}{|c|c|c|c|c|c|}
\hline Amino acids & AASP & $\begin{array}{l}\text { Strong wheat } \\
\text { flour ( } 72 \% \\
\text { ext.) control }\end{array}$ & $\begin{array}{l}\text { Whole meal } \\
\text { quinoa flour }\end{array}$ & $\begin{array}{l}\text { Corn } \\
\text { flour }\end{array}$ & $\begin{array}{l}\text { Rice } \\
\text { flour }\end{array}$ \\
\hline \multicolumn{6}{|l|}{ Essential amino acids (EAA) } \\
\hline Threonine(THR) & 4.70 & 2.53 & 3.51 & 3.49 & 3.06 \\
\hline Cystine(CYS) & - & 2.04 & 1.72 & 2.57 & 2.26 \\
\hline Methionine & - & 1.55 & 2.32 & 1.83 & 2.10 \\
\hline Valine(VAL) & 6.60 & 4.00 & 4.50 & 5.32 & 5.81 \\
\hline Isoleucine(ILE) & 5.40 & 3.35 & 3.91 & 3.30 & 4.19 \\
\hline Leucine(LEU) & 8.00 & 6.69 & 6.42 & 10.46 & 8.55 \\
\hline Tyrosine(TYR) & - & 4.41 & 3.51 & 4.22 & 5.48 \\
\hline Phenylalanine(PHE) & - & 5.22 & 4.24 & 4.59 & 5.65 \\
\hline Hisitidine(HIS) & - & 2.45 & 3.18 & 4.04 & 2.74 \\
\hline Lysine(LYS) & 6.44 & 2.04 & 5.17 & 4.04 & 3.55 \\
\hline Summation essential amino acids & - & 34.29 & 38.48 & 43.85 & 43.39 \\
\hline Meth. + Cyst. & 5.7 & & & & \\
\hline Phen. + Tyro. & 9.3 & & & & \\
\hline \multicolumn{6}{|l|}{$\begin{array}{l}\text { Non- essential amino acids (NE- } \\
\text { AA) }\end{array}$} \\
\hline Arginine(ARG) & - & 3.76 & 9.07 & 5.87 & 9.68 \\
\hline Proline(PRO) & - & 10.29 & 3.71 & 8.44 & 4.19 \\
\hline Aspartic acid (ASP) & - & 4.08 & 8.34 & 6.79 & 8.71 \\
\hline Serine(SER) & - & 4.00 & 4.11 & 3.49 & 3.71 \\
\hline Glutamic acid(GLU) & - & 28.33 & 15.63 & 17.25 & 18.06 \\
\hline Glycine(GLY) & - & 3.51 & 5.30 & 4.59 & 4.03 \\
\hline \multicolumn{6}{|l|}{ Alanine $(\mathrm{ALA})$} \\
\hline $\begin{array}{c}\text { Summation non-essential amino } \\
\text { acids }\end{array}$ & - & 56.98 & 51.13 & 54.13 & 53.87 \\
\hline Total amino acids & - & 91.27 & 89.60 & 97.98 & 97.26 \\
\hline C - PER & & 1.90 & 2.09 & 3.70 & 3.04 \\
\hline CS & & 31.68 & 68.18 & 61.11 & 55.12 \\
\hline EAAI & & 61.94 & 75.53 & 80.52 & 81.55 \\
\hline BV & & 55.78 & 70.60 & 76.03 & 77.16 \\
\hline & & & Valine & Isolucine & Lysine \\
\hline \multicolumn{6}{|c|}{ AASP :Amino acid scoring pattern FAO/WHO (1985) } \\
\hline \multicolumn{6}{|c|}{$\mathrm{C}-\mathrm{PER}=$ Calculated protein efficiency ratio. } \\
\hline \multicolumn{6}{|c|}{ CS = Chemical score } \\
\hline \multicolumn{6}{|l|}{ EAAI = Essential amino acid index. } \\
\hline \multicolumn{6}{|l|}{$\mathrm{BV}=$ Biological value } \\
\hline First-LAA = Limiting an & & & & & \\
\hline
\end{tabular}


Table 3. Farinograph and Extensograph parameters of strong wheat flour Substituted with quinoa flour

\begin{tabular}{|c|c|c|c|c|}
\hline $\begin{array}{ll}\text { Samples } & \text { Properties } \\
\end{array}$ & $\begin{array}{c}\text { Control } \\
(100 \% S W F)\end{array}$ & $\begin{array}{c}95 \% \text { SWF+ } \\
5 \% \text { QF }\end{array}$ & $\begin{array}{c}90 \% \text { SWF+ } \\
10 \% \text { QF }\end{array}$ & $\begin{array}{l}85 \% \text { SWF+ } \\
15 \% \text { QF }\end{array}$ \\
\hline $\begin{array}{c}\text { A:Farinograph parameters } \\
\text { Water absorption (\%) } \\
\text { Arrival time (min) } \\
\text { Dough development time (min) } \\
\text { Stability (min) } \\
\text { Degree of softening(B.U) after } 12 \text { min. }\end{array}$ & $\begin{array}{c}60.40 \\
1.50 \\
2.5 \\
12.00 \\
30.00 \\
\end{array}$ & $\begin{array}{c}61.20 \\
2.00 \\
3.00 \\
11.50 \\
40.00\end{array}$ & $\begin{array}{c}61.8 \\
2.00 \\
3.00 \\
8.50 \\
90.00\end{array}$ & $\begin{array}{r}62.5 \\
1.00 \\
2.00 \\
5.50 \\
130.00 \\
\end{array}$ \\
\hline $\begin{array}{l}\text { B:Extensograph parameters } \\
\text { Resistance to extension (B.U) } \\
\text { Extensibility }(\mathrm{mm}) \\
\text { Proportional number (R/E) } \\
\text { Energy }\left(\mathrm{Cm}^{2}\right)\end{array}$ & $\begin{array}{c}960.00 \\
145.00 \\
6.62 \\
210.00\end{array}$ & $\begin{array}{c}780.00 \\
155.00 \\
5.03 \\
187.00\end{array}$ & $\begin{array}{c}620.00 \\
165.00 \\
3.76 \\
152.00\end{array}$ & $\begin{array}{c}550.00 \\
105.00 \\
5.24 \\
77.00\end{array}$ \\
\hline
\end{tabular}

SWF $=$ Strong wheat flour (72 \%ext.).

$\mathrm{QF}=$ Quinoa flour.

Extensograph parameter in Table (3), the resistance to extension of the dough showed a pronounced decrease by the amounts of QF increase, the addition of QF to SWF caused dilution of gluten proteins, which resulted in a loss of dough strength. Extensibility of the dough was increased from $145 \mathrm{~mm}$ for control sample to 155 and 165 $\mathrm{mm}$ dough samples contained 5 and $10 \%$ QF respectively probably due to dilution of a cohesive gluten matrix. On the other hand, the energy of the dough (area under the curve) $\left(\mathrm{Cm}^{3}\right)$, were decreased to 187 and $152 \mathrm{Cm}^{3}$ for dough samples contained 5 and $10 \%$ QF compared to control (210 $\mathrm{Cm}^{3}$ ). Also, at levels 5 and 10\% QF substitution reduced the resistance to extension and energy of the dough, but it was suitable for baking requirements.

\section{Pan bread production}

\section{Physical properties of pan bread}

The effect of substituted of wheat flour with different levels of quinoa flour (5, 10 and $15 \%$ ) on physical properties of pan bread presented in Table (4). From results, the weight of loaf bread was increased by added quinoa flour. The volume of bread was only decreased about 7.5, 11.2 and $19 \%$ for bread substituted with 5,10 , and $15 \%$ quinoa flour, respectively compared to control sample. The decrease in bread volume probably due to the quinoa flour haven't gluten - forming protein like wheat flour and the reduction in loaf volume is due to a gluten dilution effect and the increase of alkaline - insoluble protein which is strongly correlated with poor dough mixing quality (Butaki and Dronzek, 1979). As expected, the values of specific volume recorded the similar trend as that of volume. These results are in harmony with park et al. (2005) and Rodriguez Sandoval et al (2012).

Data in Table (4) showed that, the lightness $\left(L^{*}\right)$ of the crust color revealed a significant difference $(p \leq 0.05)$ between the control sample and bread samples contained QF. The lightness decreased gradually by increasing levels of substitution increasing. The darkness (low $\left.L^{*} v a l u e\right)$ of bread could be due to Millard reaction. QF had high activity of $\alpha$ - amylase (low falling number) than wheat flour. Redness (a*value) of control sample lower than bread containing QF, the (a*value) showed non-significant differences ( $p \geq$ 0.05 ) between bread sample containing 5, 10, and $15 \%$ QF. Yellowness (b*value) decreased gradually by increasing the substation levels of QF. Generally, from results found that, the QF pan bread samples were darker and redder than control bread sample (100\% SWF). These results are in accordance with Lorenz and Coulter (1991). Bilgicli and Ibargula (2015) found that, the $\left(L^{*}\right)$ value and $\left(b^{*}\right)$ of breads show a significant darkening of both crust and crumb color on addition of QF.

\section{Sensory characteristics of pan bread}

From the data in Table (5) it could be observed that , the score of crust color was increased significantly from 5 (control sample)to $6.3,7.2$ and 7.5 for bread contained 5, 10 and $15 \%$ quinoa flour, 
of pan bread and biscuit

respectively, but crumb color was decreased gradually significantly, by increasing levels of substitution of quinoa flour. The summitry form and taste of pan bread were showed that non-significant differences $(p \geq 0.05)$ between the control pan bread and bread made from wheat flour substituted with different levels of quinoa flour. On the other hand, a higher overall acceptability was shown by bread contained 10 and $15 \%$ quinoa flour compared to other samples. Generally, pan bread made from strong wheat flour (72\% ext.)Substituted with 5 and $10 \%$ quinoa flour had the highest overall acceptability scores compared to control sample. Bread containing 5, $10 \%$ quinoa flour had acceptable sensory qualities similar or slightly higher to those obtained from control sample. These results are in agreement with Lorenz et al (1995), Chlopicka et al (2012) and Stikic et al (2012). Chase, (2014) found that, no significant differences were found between the bread control sample (100\% wheat flour) and bread containing different levels of quinoa flour.

Table 4. Physical properties of pan bread Substituted with quinoa flour

\begin{tabular}{|c|c|c|c|c|}
\hline Samples $\quad$ Properties & $\begin{array}{c}\text { Control } \\
(100 \% S W F)\end{array}$ & $\begin{array}{l}95 \% \text { SWF+ } \\
5 \% \text { QF }\end{array}$ & $\begin{array}{c}90 \% \text { SWF+ } \\
10 \% \text { QF }\end{array}$ & $\begin{array}{c}85 \% \text { SWF+ } \\
15 \% \text { QF }\end{array}$ \\
\hline \multicolumn{5}{|l|}{ A: Specific volume of loaf bread } \\
\hline Loaf weight $(\mathrm{g})$ & $254.00^{\mathrm{b}}$ & $257.50^{\mathrm{a}}$ & $257.00^{\mathrm{ab}}$ & $257.50^{\mathrm{a}}$ \\
\hline Loaf volume $\left(\mathrm{cm}^{3}\right)$ & $2372.60^{\mathrm{a}}$ & $2195.50^{b}$ & $2107.05^{c}$ & $1918.45^{d}$ \\
\hline Specific volume $\left(\mathrm{cm}^{3} / \mathrm{g}\right)$ & $9.34^{\mathrm{a}}$ & $8.53^{b}$ & $8.20^{c}$ & $7.45^{d}$ \\
\hline \multicolumn{5}{|l|}{ B: Color measurements } \\
\hline Lightness $\left(\mathrm{L}^{*}\right)$ & $60.81^{\mathrm{a}}$ & $56.55^{\mathrm{b}}$ & $54.41^{\mathrm{b}}$ & $53.21^{\mathrm{b}}$ \\
\hline Redness $\left(a^{*}\right)$ & $11.68^{b}$ & $13.10^{\mathrm{a}}$ & $12.84^{\mathrm{a}}$ & $12.98^{\mathrm{a}}$ \\
\hline yellowness $\left(b^{\star}\right)$ & $32.91^{\mathrm{a}}$ & $32.03^{b}$ & $30.00^{c}$ & $29.04^{d}$ \\
\hline
\end{tabular}

*Means in the same row followed by different letters are significantly different $(p \leq 0.05)$.

*SWF $=$ Strong wheat flour (72\%ext.). $\quad{ }^{*} \mathrm{QF}=$ Quinoa flour.

Table 5. Sensory characteristics of wheat flour pan bread and its substituted with quinoa flour

\begin{tabular}{|c|c|c|c|c|c|c|c|}
\hline \multirow{2}{*}{ Samples } & \multicolumn{7}{|c|}{ Sensory characteristics } \\
\cline { 2 - 8 } & $\begin{array}{c}\text { Crust } \\
\text { color }\end{array}$ & $\begin{array}{c}\text { Symmetry } \\
\text { form }\end{array}$ & $\begin{array}{c}\text { Crumb } \\
\text { color }\end{array}$ & $\begin{array}{c}\text { Pore } \\
\text { size }\end{array}$ & $\begin{array}{c}\text { Uniformity of } \\
\text { pore size }\end{array}$ & Taste & $\begin{array}{c}\text { Overall } \\
\text { acceptability }\end{array}$ \\
\hline Control (100\%SWF) & $5.00^{\mathrm{c}}$ & $5.00^{\mathrm{a}}$ & $5.00^{\mathrm{a}}$ & $5.00^{\mathrm{c}}$ & $5.00^{\mathrm{c}}$ & $5.00^{\mathrm{a}}$ & $5.00^{\mathrm{c}}$ \\
$95 \% \mathrm{SWF}+5 \% \mathrm{NF}$ & $6.30^{\mathrm{b}}$ & $5.00^{\mathrm{a}}$ & $4.20^{\mathrm{b}}$ & $8.30^{\mathrm{a}}$ & $8.60^{\mathrm{a}}$ & $5.00^{\mathrm{a}}$ & $6.00^{\mathrm{b}}$ \\
$90 \% \mathrm{SWF}+10 \% \mathrm{NF}$ & $7.20^{\mathrm{a}}$ & $5.00^{\mathrm{a}}$ & $3.60^{\mathrm{c}}$ & $7.00^{\mathrm{b}}$ & $8.00^{\mathrm{b}}$ & $5.00^{\mathrm{a}}$ & $7.00^{\mathrm{c}}$ \\
$85 \% \mathrm{SWF}+15 \% \mathrm{QF}$ & $7.50^{\mathrm{a}}$ & $5.00^{\mathrm{a}}$ & $2.50^{\mathrm{d}}$ & $7.00^{\mathrm{b}}$ & $7.60^{\mathrm{b}}$ & $5.10^{\mathrm{a}}$ & $7.00^{\mathrm{c}}$ \\
\hline
\end{tabular}

${ }^{*}$ Means in the same column followed by different letters are significantly different $(p \leq 0.05)$.

*SWF = Strong wheat flour (72\%ext.).

${ }^{*} \mathrm{QF}=$ Quinoa flour.

\section{Texture profile parameters of pan bread}

Hardness is an important factor in most bakery products since it is strongly correlated with consumer perception of bread freshness (Onyango et al (2010). Data presented in Figure (1) showed that, hardness of pan bread was slightly increased gradually by increasing the substitution level of quinoa flour. On the other hand, hardness of bread was gradually increased during storage of bread at $\left(25 \pm 2^{\circ} \mathrm{C}\right)$. The control pan bread sample had the highest values during storage compared to pan 
bread containing quinoa flour. Generally, the pan bread made from strong wheat flour substituted with different levels by quinoa flour is more freshness rather than the control during storage of bread to $(24,48$ and 72 h.) at room temperature $\left(25 \pm 2^{\circ} \mathrm{C}\right)$ park et al (2005) and Chase (2014) reported that, texture hardness (firmness) values of bread were gradually increased by increasing the level substitution of quinoa flour.

Springiness is a measurement of how much the bread crumb springs back after being compressed once, it is also, an important parameters to determine the staling degree of bread (Tian et al 2004).
The results in Fig. (1) showed that, springiness of bread was decreased for all samples during storage at room temperature $\left(25 \pm 2^{\circ} \mathrm{C}\right)$, the freshness of pan bread decreased from $100 \%$ (zero time) to 76,78 and $83 \%$ for bread contained 5, 10 and 15 $\%$ quinoa flour respectively after storage $48 \mathrm{~h}$ at room temperature compared to $84 \%$ for control sample. Bilgicili and Ibanogu (2015) reported that, after $24 \mathrm{~h}$ storage, the control bread (made from $100 \%$ wheat flour) had the soft texture compared to bread containing QF. On further storage to $72 \mathrm{~h}$, the bread samples become more firmness.
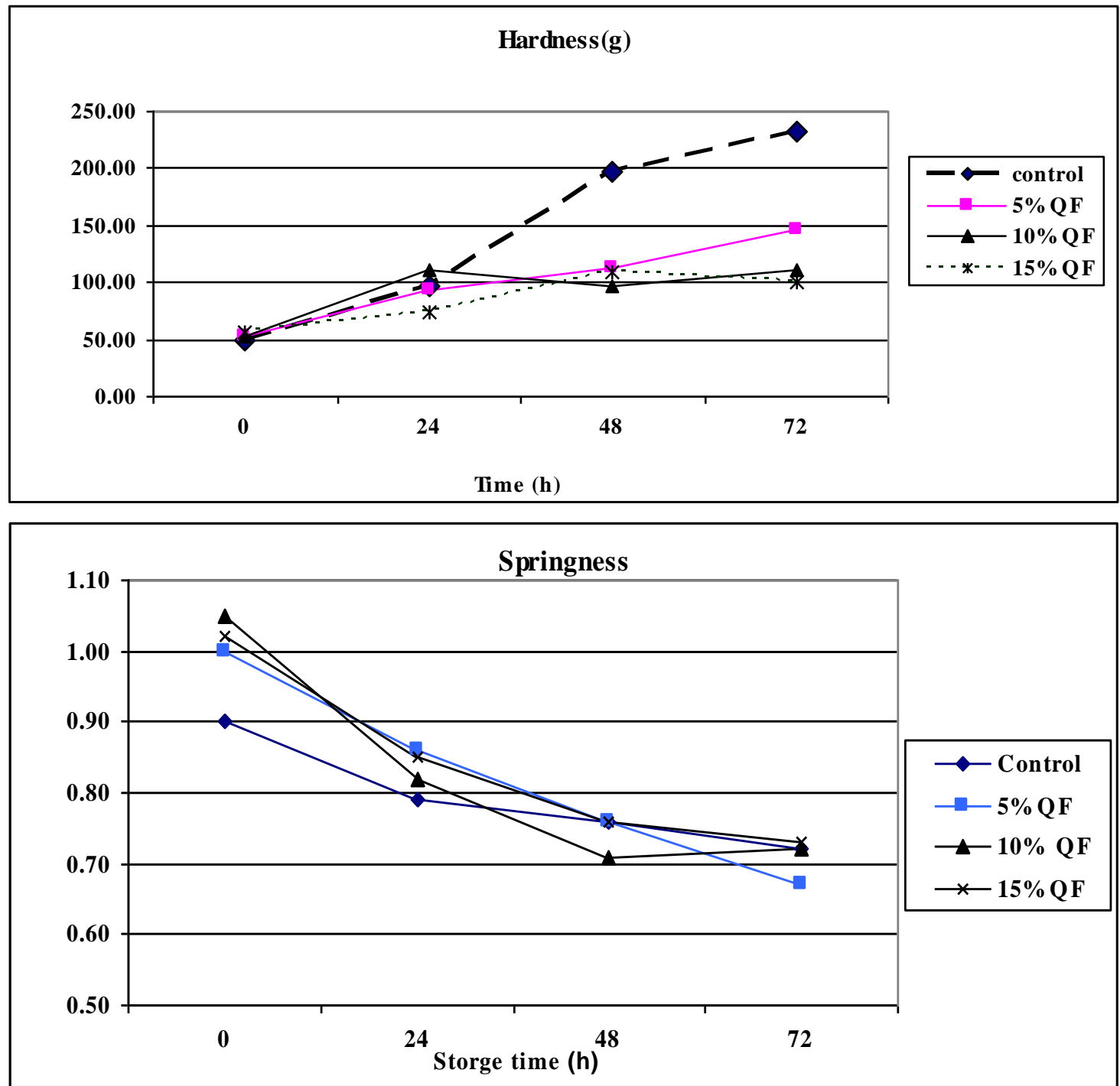

Fig. 1. Hardness and springiness of pan bread during storage at room temperature $\left(25^{\circ} \mathrm{C} \pm 2\right)$ for different periods 
of pan bread and biscuit

\section{Gluten- free biscuit production}

\section{Chemical composition of gluten- free biscuit}

The chemical composition of biscuit made from quinoa flour (QF) and its blends with different ratio from corn and rice flour are shown in Table (6), it could be concluded that, the contents of moisture, crude protein, lipids, ash and crude fiber were significantly differences $(p \leq 0.05)$ between gluten- free biscuit made from $100 \%$ QF (T1) and biscuit contained different levels from corn and rice flour (T2 and T3). The biscuit (T1) had the highest amounts of all these compounds compared to (T2 and T3). On the other hand, nitrogen free extract (NFE) was a gradually increased by increasing levels of corn and rice flour. The highest contents of crude protein levels, ash and crude fiber in biscuit (T1) probably due to QF had higher amounts of these compounds than corn and rice flour (Table 1). These differences in chemical compounds are expected due to the complementation of QF with CF and RF that contain different amounts of proteins, lipids, ash and crude fiber. These results are in agreement with Păucean et al (2015).

Table 6. Proximate composition of biscuit made from composite flour (\%on dry weight basis)

\begin{tabular}{|c|c|c|c|c|c|c|}
\hline Flour samples & Moisture & $\begin{array}{c}\text { Crude } \\
\text { protein }\end{array}$ & Lipids & $\begin{array}{c}\text { Crude } \\
\text { Fiber }\end{array}$ & Ash & NFE $^{\star}$ \\
\hline Control (100\%QF ) & $5.63^{\mathrm{a}}$ & $15.89^{\mathrm{a}}$ & $29.47^{\mathrm{a}}$ & $2.19^{\mathrm{a}}$ & $1.99^{\mathrm{a}}$ & $50.46^{\mathrm{c}}$ \\
$70 \% \mathrm{QF}+15 \% \mathrm{CF}+15 \% \mathrm{RF}$ & $5.18^{\mathrm{b}}$ & $13.82^{\mathrm{b}}$ & $26.46^{\mathrm{b}}$ & $1.90^{\mathrm{b}}$ & $1.65^{\mathrm{b}}$ & $56.17^{\mathrm{b}}$ \\
$40 \% \mathrm{QF}+30 \% \mathrm{CF}+30 \% \mathrm{RF}$ & $4.79^{\mathrm{c}}$ & $11.73^{\mathrm{c}}$ & $23.91^{\mathrm{c}}$ & $1.50^{\mathrm{c}}$ & $1.27^{\mathrm{c}}$ & $61.59^{\mathrm{a}}$ \\
\hline
\end{tabular}

${ }^{*}$ Means in the same column followed by different letters are significantly different $(p \leq 0.05)$

*Nitrogen free extracts (NFE): Calculated by difference.

${ }^{*} \mathrm{QF}=$ Quinoa flour.

${ }^{*} \mathrm{CF}=$ Corn flour.

${ }^{*} \mathrm{RF}=$ Rice flour.

\section{Physical properties of gluten- free biscuit}

It could be observed from the results in Table (7) blending quinoa, corn and rice flours in different percentages significant observation $(p \leq 0.05)$ could be noticed for weight, specific volume, thickness, diameter and spread ratio of biscuit due to the results are consistent with results reported by Paucean et al (2015). Volume and specific volume of biscuit were gradually increased by increasing levels of CF and RC compared to control sample (T1). No difference between (T1) and (T2) for diameter, the changes in diameter and thickness reflected the spread ratio which was constantly decreased from 12.0 (T1) to 11.1(T2) or (T3) in the case of biscuit obtained from blends with corn and rice flour. Other studies reported that spread ratio of biscuit increased by increasing the levels with QF (Paucean et al 2015). Brito (2015) which would explain the decrease of volume in cookies with higher amount of quinoa flour compared to those of corn starch.
The color characteristic $\left(L^{*}, a\right.$ * and $\left.b^{*}\right)$ of gluten - free biscuit crust are given in Table (7). The crust color of biscuit samples made from composite flour (T2) had slightly significant $(p \leq 0.05)$ lower $L$ * value compared to (T1) and (T3). Also, redness $\left(a^{*}\right)$ values were significantly differences between (T3) and (T1and T2). The high $\left(\mathrm{a}^{*}\right)$ values of biscuit contained more amounts of QF (T1 and T2) could be due to high protein content (Table 1). The containing more protein can increase the Millard reaction and brown color (Gomez et al 2003). Also, from the results in Table (7) biscuit made from CF or RF (T3) had higher $b$ * values (31.3) than biscuit samples containing higher amount of QF Generally, it could be concluded that the biscuit contained more of QF was darker compered to another sample contained more corn and rice flour. Brito et al (2015) reported that corn starch had positive effect on the lightness of the cookies, but increased amount of quinoa flour in the mixture resulted in darker product. 
Table 7. Physical properties of gluten -free biscuit

\begin{tabular}{|c|c|c|c|}
\hline Samples & $\begin{array}{l}\text { Control (100\%QF) } \\
\text { Treatment (1) }\end{array}$ & $\begin{array}{c}70 \% \text { QF+15\%CF+15\%RF } \\
\text { Treatment }(2)\end{array}$ & $\begin{array}{c}40 \% Q F+30 \% C F+30 \% R F \\
\text { Treatment (3) }\end{array}$ \\
\hline \multicolumn{4}{|l|}{ A:Physical characteristics } \\
\hline Weight (g) & $13.30^{a}$ & $12.86^{b}$ & $12.53^{c}$ \\
\hline Volume $\left(\mathrm{Cm}^{3}\right)$ & $19.80^{\mathrm{C}}$ & $20.30^{b}$ & $20.70^{\mathrm{a}}$ \\
\hline Specific volume $\left(\mathrm{Cm}^{3} / \mathrm{g}\right)$ & $1.49^{\mathrm{c}}$ & $1.58^{\mathrm{b}}$ & $1.65^{\mathrm{a}}$ \\
\hline Thickness (mm) & $5.00^{\mathrm{a}}$ & $5.40^{\mathrm{a}}$ & $5.50^{\mathrm{a}}$ \\
\hline Diameter (mm) & $60.00^{\mathrm{a}}$ & $60.00^{\mathrm{a}}$ & $61.00^{\mathrm{a}}$ \\
\hline Spread ratio $(\mathrm{d} / \mathrm{t})$ & $12.00^{\mathrm{a}}$ & $11.10^{\mathrm{a}}$ & $11.09^{\mathrm{a}}$ \\
\hline \multicolumn{4}{|l|}{ B:Color measurements } \\
\hline Lightness $\left(L^{\star}\right)$ & $56.43^{b}$ & $55.74^{c}$ & $63.56^{\mathrm{a}}$ \\
\hline Redness $\left(\mathrm{a}^{\star}\right)$ & $8.45^{b}$ & $8.96^{a}$ & $5.95^{c}$ \\
\hline yellowness $\left(b^{\star}\right)$ & $27.76^{c}$ & $29.43^{b}$ & $31.30^{a}$ \\
\hline
\end{tabular}

${ }^{*}$ Means in the same row followed by different letters are significantly different $(p \leq 0.05)$.

${ }^{*} \mathrm{QF}=$ Quinoa flour.

${ }^{*} \mathrm{CF}=$ Corn flour.

${ }^{*} \mathrm{RF}=$ Rice flour.

\section{Sensory characteristics of quinoa flour biscuit substituted with corn and rice flour}

Form the sensory evaluation results (Table 8) it could be seen that, there were no significant difference $(P \geq 0.05)$ among control sample $(100 \% Q F)$, and biscuit samples made from treatment (2) or treatment (3) in all sensory characteristic with exception, the surface characteristic of biscuit contained corn and rice flour with significant reduced
$(P \leq 0.05)$ when compared with control sample. Also, the texture of biscuit contained corn and rice flour (treatment 2 and 3) with increased significantly with compared with control sample. The total score acceptability for these samples ranged from 39.1 to 39.4 , no significant differences between control sample and samples contained corn and rice flour. Generally, substitution of quinoa flour with corn and rice flour were affected on the acceptably of biscuit samples.

Table 8. Sensory characteristics of gluten- free biscuit

\begin{tabular}{|c|c|c|c|c|c|c|c|}
\hline \multirow{2}{*}{ Biscuit samples } & $\begin{array}{c}\text { Crust } \\
\text { color }\end{array}$ & $\begin{array}{c}\text { Surface } \\
\text { characteristics }\end{array}$ & $\begin{array}{c}\text { Crumb } \\
\text { color }\end{array}$ & Texture & Taste & $\begin{array}{c}\text { Mouth } \\
\text { feel }\end{array}$ & $\begin{array}{c}\text { Total score } \\
\text { acceptability }\end{array}$ \\
\cline { 2 - 8 } & $\mathbf{1 0}$ & $\mathbf{1 0}$ & $\mathbf{1 0}$ & $\mathbf{1 0}$ & $\mathbf{1 0}$ & $\mathbf{1 0}$ & $\mathbf{6 0}$ \\
\hline Control(100\% QF ) & $7.90^{\mathrm{a}}$ & $7.20^{\mathrm{a}}$ & $5.60^{\mathrm{a}}$ & $6.60^{\mathrm{b}}$ & $6.00^{\mathrm{a}}$ & $6.10^{\mathrm{a}}$ & $39.40^{\mathrm{a}}$ \\
$70 \% \mathrm{QF}+15 \% \mathrm{CF}+15 \% \mathrm{RF}$ & $7.60^{\mathrm{a}}$ & $6.60^{\mathrm{ab}}$ & $5.80^{\mathrm{a}}$ & $7.10^{\mathrm{a}}$ & $6.00^{\mathrm{a}}$ & $6.30^{\mathrm{a}}$ & $39.40^{\mathrm{a}}$ \\
$40 \% \mathrm{Q}+30 \% \mathrm{CF}+30 \% \mathrm{RF}$ & $7.40^{\mathrm{a}}$ & $6.00^{\mathrm{b}}$ & $6.10^{\mathrm{a}}$ & $7.30^{\mathrm{a}}$ & $5.80^{\mathrm{a}}$ & $6.50^{\mathrm{a}}$ & $39.10^{\mathrm{a}}$ \\
\hline
\end{tabular}

${ }^{*}$ Means in the same column followed by different letters are significantly different $(p \leq 0.05)$

${ }^{*} \mathrm{QF}=$ Quinoa flour.

${ }^{*} \mathrm{CF}=$ Corn flour.

${ }^{\star} \mathrm{RF}=$ Rice flour 

of pan bread and biscuit

Texture profile parameters of gluten- free biscuit

From the results in Table (9), it could be showed that, there were non- significant differences ( $p \geq 0.05)$ between control sample (T1) and biscuit sample contained corn and rice flour (T2 and T3) in height $(\mathrm{mm})$, distance $(\mathrm{mm})$, max distance $(\mathrm{mm})$ and peak time (s). But the biscuit samples containing corn and rice flour with different levels (T2 and T3) were significantly different ( $p \leq 0.05)$ compared to control sample (T1) in hardness $(\mathrm{g})$ and gradient total $(\mathrm{g} / \mathrm{mm})$. On the other hand, results showed that there were significant differences $(p \leq 0.05)$ in stickiness between control biscuit sample (100\% quinoa flour) (T1) and sample contained corn and rice flour (T2 and T3). Biscuit sample made from (T3) had the highest value of stickiness $(5.0 \mathrm{~g})$ compared to control sample $(2.5 \mathrm{~g})$.

Table 9. Texture profile parameters of gluten -free biscuit

\begin{tabular}{|c|c|c|c|c|c|c|c|}
\hline Biscuit samples & $\begin{array}{c}\text { Hardness } \\
\text { (g) }\end{array}$ & $\begin{array}{c}\text { Height } \\
\text { (mm) }\end{array}$ & $\begin{array}{c}\text { Distance } \\
(\mathbf{m m})\end{array}$ & $\begin{array}{c}\text { Gradient } \\
\text { Total } \\
(\mathrm{g} / \mathrm{mm})\end{array}$ & $\begin{array}{c}\text { Max } \\
\text { Distance } \\
(\mathrm{mm})\end{array}$ & $\begin{array}{c}\text { Peak } \\
\text { Time (s) }\end{array}$ & $\begin{array}{c}\text { Stickiness } \\
\text { (g) }\end{array}$ \\
\hline Control( 100\% QF) (T1) & $1910.50^{a}$ & $55.06^{b}$ & $0.58^{a}$ & $3225.00^{a}$ & $2.13^{a}$ & $0.15^{a}$ & $2.50^{\mathrm{a}}$ \\
\hline $\begin{array}{c}70 \% Q F+15 \% C F+15 \% \\
R F(T 2)\end{array}$ & $1446.50^{b}$ & $56.17^{\mathrm{a}}$ & $0.58^{a}$ & $\underset{b}{2430.00^{a}}$ & $2.44^{a}$ & $0.15^{\mathrm{a}}$ & $1.50^{\mathrm{a}}$ \\
\hline $\begin{array}{c}40 \% \mathrm{QF}+30 \% \mathrm{CF}+30 \% \\
\operatorname{RF}(\mathrm{T} 3)\end{array}$ & $1418.50^{b}$ & $56.19^{a}$ & $0.57^{\mathrm{a}}$ & $2406.50^{b}$ & $2.28^{a}$ & $0.15^{\mathrm{a}}$ & $5.00^{b}$ \\
\hline
\end{tabular}

${ }^{*}$ Means in the same column followed by different letters are significantly different $(p \leq 0.05)$

${ }^{*} \mathrm{QF}=$ Quinoa flour.

${ }^{*} \mathrm{CF}=$ Corn flour.

${ }^{*} \mathrm{RF}=$ Rice flour.

\section{CONCLUSION}

The results of the current study show that the whole meal quinoa flour had the higher amounts of protein, lipids, ash and crude fiber than other raw materials under investigation. Also, QF, CF and RF can utilized as a good protein sources in bakery products. Bread containing 5 and $10 \%$ quinoa flour recorded acceptable sensory qualities similar or slightly higher to those obtained form $10 \%$ wheat flour.Also, the rate of staling of pan bread contained quinoa flour lower than bread made from $100 \%$ wheat flour. On the other hand, it is worth mentioning that the gluten -free biscuit mad from $100 \%$ quinoa flour or that of corn and rice -quinoa composite flour gave the biscuit with more sensory acceptable.

\section{REFERANCE}

A.A.C.C. 2012. International Methods approved of the American Association of Cereal Chemists, $11^{\text {th }}$ ed., American Association of Cereal Chemists, INC., St. Paul, Minnesota, USA.
Adeyeye, S.A.O., Adebayo-Oyetoro, A.O. and Omoniyi, S.A. 2017. Quality and sensory properties of maize flour cookies enriched with soy protein isolate. J. of Cogent. Food and Agric., 3, 1-11.

A.O.A.C. 2000. Association of Official Analytical Chemists International, William, 17th ed., Gaithersbuy MD, USA.

Atef A., Abou-Zaid, El-Faham S.Y., Wafaa H. Emam 2014. Use of Quinoa Meal to Produce Bakery Products to Celiac and Autism Stuffs. Int. J. of Sci. and Research (IJSR), 3, 13441354.

Bassinello P.Z., Freitas D.G.C., Ascheri J.R., Takeitib C.Y., Carvalhoa R.N., Koakuzua S.N. and Carvalhoc A.V. 2011. Characterization of cookies formu-lated with rice and black bean extruded flours. J. Proc. Food Sci., 1, 1645-1652.

Bhaduri S. 2013. A Comprehensive Study on Physical Properties of Two Gluten-Free Flour Fortified Muffins. J. of Food Proc. and Technol., 4, 4-7. 
Bilgiçli N. and İbanoğlu Ş. 2015.Effect of pseudo cereal flours on some physical, chemical and sensory properties of bread. J. Food Sci. Technol., 11, 7525-7529.

Brito I.L., Souza E.L., Felex S.S.S., Madruga M.S., Yamashita F. and Magnani M. 2015. Nutritional and sensory characteristics of gluten-free quinoa (Chenopodium quinoa Willd)based cookies development using an experimental mixture design. J. of Food Sci. and Technol., 9, 5866-5873.

Butaki R.C. and Dronzek B. 1979. Effect of protein content and wheat verity on relative viscosity, solubility and electrophoresis properties of gluten protein. Cereal Chem., 56, 162-165.

Cauvain S.P. and Linda S. Young 2007. Breadmaking process. In: " Technology of Breadmaking". pp. 28-33, Chap. 2, (2 ${ }^{\text {nd }} E d$.) Springer, New York, USA.

Chase, C.B. 2014.Comparison acceptability of gluten - free yeast breads made with quinoa flour. MSc. Thesis. pp. 37-40.

Chlopicka J., Pasko P., Gorinstein A. and Zagrodzki P. 2012.Total phenolic and total flavonoid content, antioxidant activity and sensory evaluation of pseudocereal breads. LWTFood. Sci. and Technol., 46, 548-555.

Enriquez V., Peltzer M., Raimundi A., Tosi V. and Pollio M.L. 2003. Characterization of wheat and quinoa flour blends in relation to their breadmaking quality. J. Arg. Chem. Soc., 91, 47-54.

FAO/WHO.1990. Protein quality evaluation .Report of a joint FAO-WHO expert Consultation. Rome, Italy.

Gęsiński K. and Nowak K. 2011. Comparative analysis of the biological value of protein of Chenopodium quinoa willd. and Chenopodium album L. Part I. amino acid composition of the seed protein. Acta Sci. Pol., Agric., 3, 47-56.

Gomez M., Ronda F., Blanco C., Caballero P. and Apeseguia A. 2003. Effect of dietary fibre on dough rheology and bread quality. Eur. Food Research Technol., 216, 51-56.

Gómez-Caravaca A.M., Segura-Carretero A., Fern A. and Caboni M.F. 2011. Simultaneous determination of phenolic compounds and saponins in quinoa (Chenopodium quinoa Willd) by a liquid chromatography-diode array detectionelectrosprayionization-time-of-flight mass spectrometer methodology. J. Agric. Food Chem., $59,10815-10825$.
Larmond E. 1970. Methods for sensory evaluation of food. Food Research Institute, Canada Dept. Agric. Publ. 1284. Ottawa.

Lorenz K. and Coulter L. 1991 . Quinoa flour in bakedproducts. Plant Foods for Hum. Nutrition, 41, 213-223.

Lorenz K., Coulter L. and Johnson D. 1995. Functional and sensory characteristics of quinoa in foods. G. Charalambous (Ed.), Food Flavors: Generation, Analysis and Process Influence, pp. 1031-1041.

Mareti, M.C.; Grossmann, M.V.E.; Benassi, M. T. 2010. Physical and sensorial characteristics of cookies containing defatted soy flour and oat bran. Food Sci. Technol., 4, 878-883.

Milovanović M.M., Demin M.A., Vucelić-Radović B.V., Žarković B.M. and Stikić R.I. 2014. Evaluation of the nutritional quality of wheat bread prepared with quinoa, buckwheat and pumpkin seed blends. J. of Agric. Sci., 3, 319328.

Nandeesh K., Rajiv J. and Rao G.V. 2011. Effect of differently treated wheat bran on rheology, microstructure and quality characteristics of soft dough biscuits. J. of Food Proc. and Preservation, 35,179-200.

Olaoya O.A.A., Onilude A.A. and Idown O.A. 2006. Quality characteristics of bread produced from composite flours of wheat and soy beans. Afr. J. Bioethanol., 5, 1102-1106.

Onyango C., Mutungi C., Unbehend G., Meinolf, G. and Lindhaue R.M.G. 2010. Rheological and baking characteristics of batter and bread prepared for pregelatinised cassava starch and sorghum and modified using microbial transglutaminase. J. of Food Eng., 97, 465-470.

Park S.H., Maeda T. and Morita N. 2005. Effects of whole quinoa flours and lipase on chemical, rheological and breadmaking characteristics of wheat flour. J. of Applied Glycoscience, 4, 337-343.

Păucean A., Man S., Muste S. and Pop A. 2015. Effect of quinoa flour addition on characteristics of rice gluten-free cookies. Journal of Agroalimentary quality. Proc. and Technol., 4, 371378.

Rodriguez-Sandoval E., Sandoval G. and Cortes-Rodríguez M. 2012. Effect of quinoa and potato flours on the thermomechanical and breadmaking properties of wheat flour. Brazilian J. of Chem. Eng., 29, 503-510. 

of pan bread and biscuit

Rosell C.M., Cortez G. and Repo-Carrasco R. 2009. Breadmaking use of Andean crops quinoa, kañiwa, kiwicha, and tarwi. Cereal Chem., 4, 386- 392.

Sai-Manohar R. and Haridas-Rao P. 1997. Effect of sugars on the rheological characteristics of biscuit dough and quality of biscuit. J. Sci. Food Agric., 75, 383-390.

SPSS. 2000. Statistical Package for Social Sciences. SPSS for Winds Version 19, SPSS Inc., Chicago, IL, USA.

Stikic R., Glamoclija D., Demin M., VucelicRadovic B., Jovanovic Z., MilojkovicOpsenica D., Jacobsen S. and Milovanovic M. 2012. Agronomical and nutritional evaluation of quinoa seeds (Chenopodium quinoa Willd.) as an ingredient in bread formulations. J. of Cereal Sci., 55, 132-138.

Tian Y.Q., Li Y., Jin Z.Y., Xn X.M., Wang J.P., Jiaa A.Q., Yu B. and Talba T. 2004. B-cyclodextrin (B-CD): A new approach in bread staling. Thermochemical Acta, 484, 2226.

Tharise N., Julianti E. and Nurminah M. 2014. Evaluation of physico-chemical and functional properties of composite flour from cassava, rice, potato, and xanthan gum as alternative of wheat flour, Int. Food Research J., 4, 16411649.

Tong Q., Zhang X., Wu F., Tong J., Zhang P. and Zhang J. 2010. Effect of honey powder on dough rheology and bread quality. Food Research Int., 43, 2284-2288.

Waller R.A. and Duncan D.B. 1969. A bays rule for symmetric multiple comparison problems. J. of the American Statistical Association, 67, 253.

Wade P. 1988. Biscuit, cookies and crackers, Vol.1, Recipe of biscuit used during investigation. pp.102-994. Applied Science Publishers LTD, London, UK. 


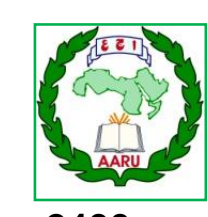

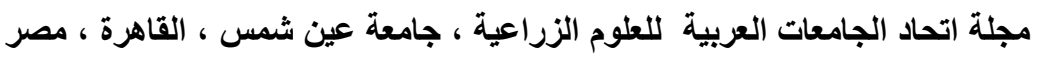

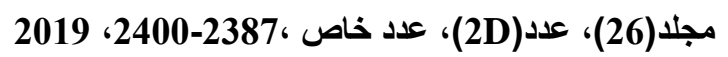

Website: http://strategy-plan.asu.edu.eg/AUJASCI/

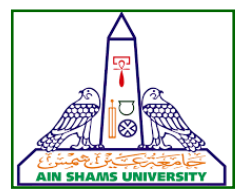

2400

تأثير استبدال دقيق القمح بمطحون الكينوا على جودة خبز القوالب والبسكويت الخالي من الجلوتين

[175]

عماد معوض محمد معوض1 ${ }^{1}$ - إبراهيم رزق سيد أحمد رزق 2 - ياسر فكري محمد كثك 2 ـ

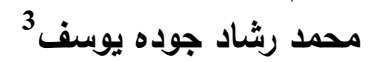

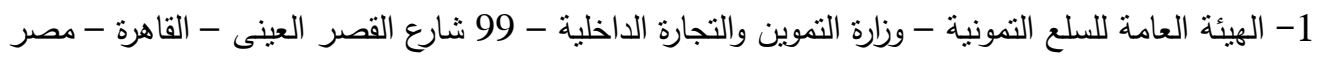

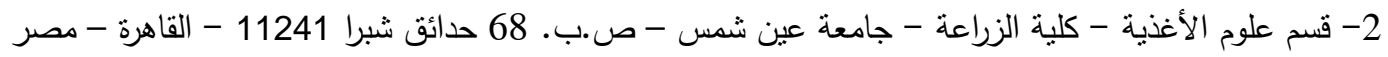

3- قسم بحوث الخبز والعجائن - معهد بحوث تكنولوجيا الأغذية - مركز البحوث الزئ الزراعية - الجيزة - مصر

*Corresponding author: emad.coach@yahoo.com

Received 29 April, 2018

Accepted 4 June, 2018

الكينوا أفضل من عينة المقارنة في بعض الخواص الحسية لخبز القوالب منل لون القصرة، حجم التقوب التباب والقبول العام. ازدادات درجة الصلابة والبة لانخفضت

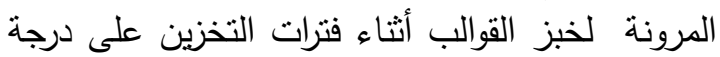

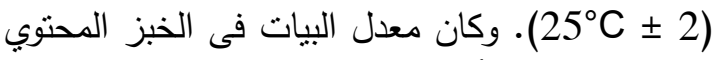
على دقيق الكينوا أقل من عينة المقارنة.

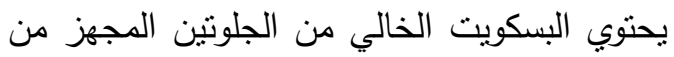

100\% دقيق الكينوا على نسبة مرتفعة من البرتئ البرتين

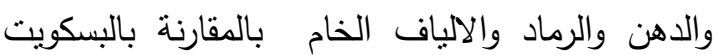

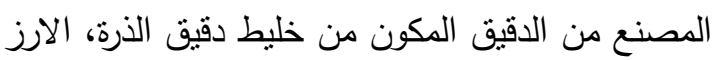

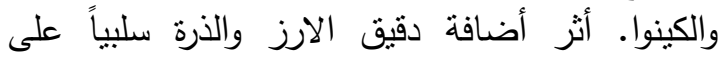

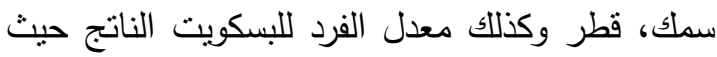

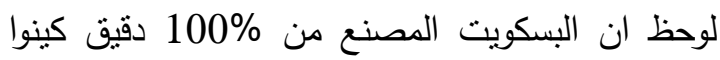

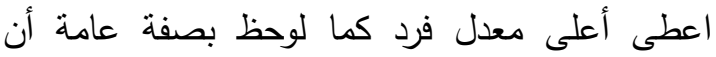

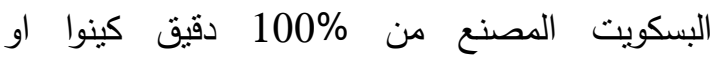
البسكويت المصنع من خليط من دقيق الذرة والارز

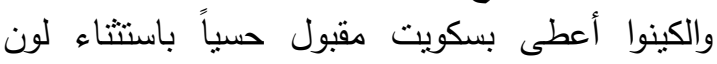
البسكويت المجهز من دقيق الكينوا والذي كان داكناً .

الكلمات الدالة: دقيق القمح، دقيق الكينوا، دقيق الذرة،

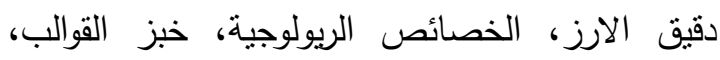

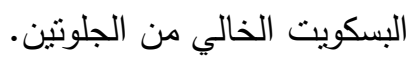

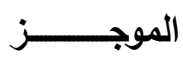

يهدف البحث إلى دراسة تأثثر استبدال دقيق القمح

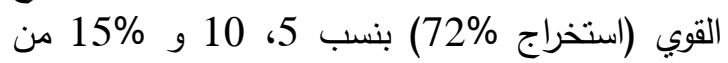
دقيق الكينوا على خصائص جودة خبز القوالب، القبا

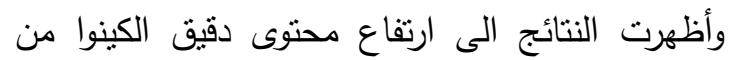

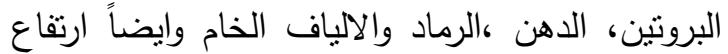

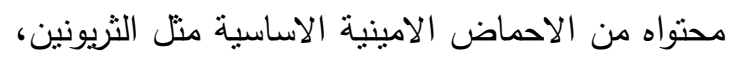

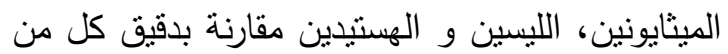

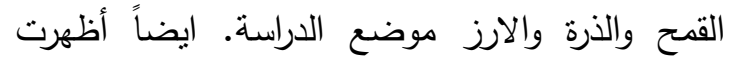

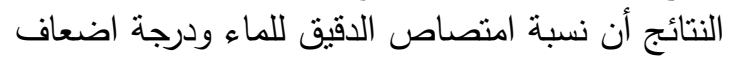

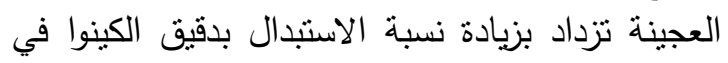
الخلطات ولكن انخفض وقت ثنبات العجين، الانسيابية

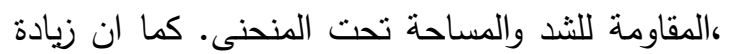

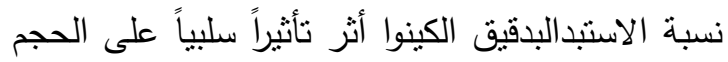

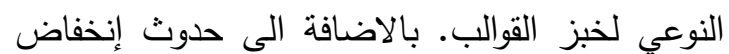

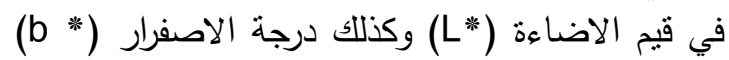

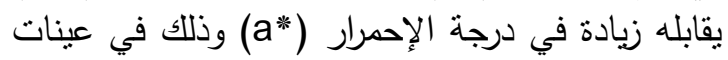

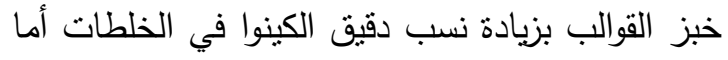
الخصائص الحسية لخبز القوالب مثل صفئ صنّ الطعم وتماتل الثكل أظهرت النتائج عدم وجود اختلافات الثرات

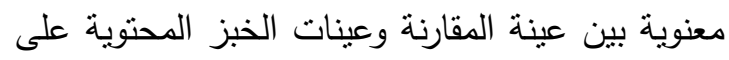

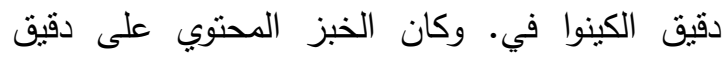

